\title{
Dissenting voices within political theory Voegelin's quest for symbols and Strauss's search for the philosopher
}

\begin{abstract}
The paper summarizes the nature of Eric Voegelin's and Leo Strauss's methodological approaches to the study of the history of political thought, in particular, the Western political thought. The paper concludes that in both cases the thinkers stray away from the mainstream, which is currently represented by contextualism. However, in their dissenting voices both authors take very different routes. Voegelin focuses on political symbols which are grounded in the metaphysical experience of their creators, and Strauss focuses on the perennial question of philosophy and classical, discursive rationality as the criterion of philosophical inquiry. They also differ in their opinions on the role of the political philosopher. For Voegelin, the philosopher is a defender or a co-creator of political creeds. For Strauss $\mathrm{s} /$ he is mainly the educator of politically savvy youths and, above all, the defender of philosophy as the most noble pursuit of the mind. The paper concludes by pointing out the importance and prominence of both thinkers.
\end{abstract}

Key words: Voegelin, Strauss, political philosophy, symbols, history of political thought

\section{Introduction ${ }^{1}$}

$\mathbf{T}$ here is a contemporary consensus on the highly historical and contextual approach to political philosophy. This consensus is especially strong in Europe and was partly derived from the tradition of the Cambridge School. The seminal article that puts forwards the methodological manifesto of this group of scholars is Quentin Skinner's piece entitled: "Meaning and Understanding in the History of Ideas" (1969, pp. 3-51). In the text, Skinner tries to defend political thought both from reducing it to a mere result of the underlying economic factors and turning it into a set of timeless philosophical questions. In the New World this approach was discussed in the famous polemic between J. G. A. Pocock (1975, pp. 385-401) - a historian of ideas inspired by the Cambridge School, and Harvey Mansfield (1975, pp. 372-384) - a talented student of Leo Strauss, who like Strauss defended the perennial character of the questions political philosophy asks.

It is, indeed, interesting that in the modern study of political philosophy the venerable European centers, which formulated the historical and contextual approach, found dissenters mainly on the other side of the Atlantic. At the same time, the dissenting voices were often those of European scholars who found a very responsive audience ${ }^{2}$

1 This article has been written within the research project: „Podstawowa literatura przedmiotu a kształt współczesnej politologii. Political Science, Politische Wissenchaft i Politologija w ujęciu porównawczym" (DEC-2012/05/B/HS5/00597) - financed by the National Science Center in Poland.

${ }^{2}$ I explore the deeply rooted American tradition of anti-historicism and the proclivity to produce a philosophy of natural rights and attract anti-historicist thinkers in another article (see: Kuź, 2013). 
in the USA. Two of the critics of the Cambridge School in particular became prominent because of their unique methodological approaches to the history of political philosophy. Those thinkers are: Eric Voegelin and Leo Strauss.

In their rejection of contextualism in thinking about political ideas, Voegelin and Strauss up to a point resembled John Rawls, whose analytical philosophy became another famous American response to European historicality. This paper will, however, only mention Rawls in passing. This is mainly for three reasons. Firstly, Rawlsian political philosophy is not too deeply concerned with tradition. It has its own language and logic that connects concepts that are, indeed, sui generis. In other words, Rawls did not argue about Plato in the sense Strauss, Voegelin and Pocock did, he was self-sufficient and became his own great philosopher, with all the drawbacks and the advantages of this precarious position. Secondly, a detailed discussion of Rawls's approach to history cannot be conducted in the confines of one, brief paper. Thirdly, Rawls did not share the same cultural and educational background that Strauss and Voegelin had in common, and thus there are good reasons for discussing the two together, and in separation from Rawls.

Nevertheless, for all their peculiarities Strauss, Voegelin and Rawls had one important feature in common. They all wanted to escape something Strauss called 'historicism', they all wanted to find in political philosophy something that is 'simply' true, rather than contingent on historical context. Both Eric Voegelin and Leo Strauss formed their own schools of the study of history of political thought. Those schools are still relatively powerful but, nevertheless, situated on the fringes of the contextualist mainstream. In a way, both Strauss and Voegelin focus on a politico-philosophical problem, albeit in different ways. Hence the rivalry (and perhaps some bitterness) between the 'Straussians' and the 'Voegelinians' (see: Sandoz, 2006, pp. 120-126).

This paper highlights some of the main points in this dispute with special focus on the relations between transcendental symbols and the concept of the political. Moreover, it discusses the divergent intellectual anthropologies present in the writings of Strauss and Voegelin. According to this analysis, for Voegelin all politics becomes voiced through symbols. Political symbolisms (systems of symbols), in turn, are generated through a process Voegelin calls differentiation. However, at the base of every differentiation one always finds its "experiential basis" - i.e. what the political thinker believes to be the experience of the transcendental. For Voegelin this experiential basis of being is very ecumenical, both everyday politics and complex political theories participate in it alike. The political philosopher is thus working within the same symbolisms as the rest of the society, s/he, however, understands them at a slightly deeper and perhaps more 'mystical' level. Voegelin considers a thinker who does not follow this pattern an intellectually dishonest impostor, who is interested only in power for power's sake. From religious studies Voegelin borrows the term "Gnostic" for a particularly important group of such impostors.

Strauss disagrees, for him true political philosophy is always completely separated from the doxa of the common men or the pistis of religion. He is, in this respect, a great student of Plato. For Strauss, only the philosophers participate in the deeply rational understanding of politics and, indeed, their sole mission is to guard this understanding. Moreover, ordinary politics and religion is a threat to political philosophy, since it can lead to the persecution of philosophers. 
What Strauss agrees on with Voegelin, however, is that political thinkers should not seek direct power. Voegelin, nevertheless, permits some of them to seek power indirectly, by explaining the nature of the symbols humans use in their political language. Strauss, especially in his polemic with Alexandre Kojève (1969), precludes this. Pure political philosophy has to be separated from political activity. The men and women who participate in real politics will naturally benefit from knowing political philosophy; but they can only treat it as a moral and intellectual exercise. True political philosophy for Strauss, by definition, cannot be translated into political action.

\title{
Voegelin's path to political symbols
}

Voegelin was born in 1901 in Cologne. In 1922 he received his doctoral degree in Vienna, in law under Hans Kelsen, a famous neo-positivist scholar. ${ }^{3}$ Significantly, however, in his later work Voegelin became one of the most vociferous critics of positivism and the concept of progress. As for the methodological concerns, Voegelin described the 'positive' approach as deeply reductionist. To counter this tendency, already in his early works Voegelin turned towards exploring the symbolic grounds of politics. He was still working at the University of Vienna at the time of the Austrian Anschluss. As a matter of fact, shortly before this event he published a work in which he addressed the theologicopolitical problem of modern ideologies. The book was entitled Die Politischen Religionen (originally published in 1938), or simply Political Religions (Voegelin, 1999b). Voegelin, therefore, became one of the first authors to identify and describe the structural and symbolic similarities between modern political ideologies and religions (Gontier, 2009 , p. 1). At the same time, in another work published in the same period (in 1934), Voegelin criticized Carl Schmitt's decisionism embodied in the concept of the total state (Voegelin, 1999a, pp. 58-63).

Schmitt's philosophy, for Voegelin, was rooted in the vision of the metaphysical as an irrational, 'Dionysian' force that trumps any order. As Paul Gontier rightly claims:

\begin{abstract}
"Transcendence does not have the same meaning for Schmitt and for Voegelin. For the former, it essentially means the radical heteronomy of a decision vis-à-vis all forms of legal rationality. For Voegelin, it refers to the subsumption of the legal order by a higher ethical and metaphysical order in which it finds its meaning. The two political structures are linked to two very different theological structures. Schmitt's decisionist political structure fits with a theology of potentia absoluta Dei, which finds its roots in late medieval Scotist or Ockhamist theologies. Voegelin refers to a theology of a Platonic type, for which the divine is not understood as radical otherness, but as the transcendent good toward which the human soul is naturally open" (2009, p. 3).
\end{abstract}

This approach also defines the calling of the student of political philosophy. According to Voegelin, the grand mission of political philosophy is precisely to draw a line be-

${ }^{3}$ I am also preparing an article that deals with Voegelin's intellectual biography in more detail, it will appear in Polish in the forthcoming first edition of the "Rambler" magazine. The working title of the article reads: "Voegelin - demonolog współczesności" ["Voegelin the Demonologist of Modernity"]. 
tween symbols that are grounded in a larger philosophical order and the violent arbitrariness of politics grounded in raw force. He recognized potentia absoluta Dei, but believed that politics must never touch it or claim to hold it, even if it sees it on the distant horizon of pure spirituality. Of course, this made Voegelin more 'Apollonian', if we are to follow Nietzsche's famous metaphor.

Moreover, looking for an order in faith created a troubled relation between Voegelin and Christianity. The German-American thinker on the one hand credited the JudeoChristian tradition with furnishing the West with its crucial political symbols, and on the other claimed that all the "the specifically modern problems of representation" had the same origin (Voegelin, 1987, p. 110). In other words, the modern ideologies Voegelin so despised would be impossible in the ordered world of the Greco-Roman political and religious symbols. And even if contemporary ideologies rejected the Judeo-Christian piety, they were still tied to its understanding of political philosophy and specifically the problem of reflecting the divine in the immanent. The cosmological question here was whether the metaphysical order has always permeated all being, or whether order was created in an arbitrary and violent act in which the reason of God conquered chaos. Order constitutes for Voegelin the basic political symbol, hence the title of his opus mangum (Order and History). For him, the creation of every temporal, political order was a symbol of the mythical creation of the cosmos.

But, of course, most religions will hold that even after creation the world needs divine protection from chaos. In the same way, Voegelin was confident that every political order worthy of the name deserved protection from arbitrary violence. Therefore, in his early writings he tried to accomplish what he saw as the mission of a historian of political philosophy, by exposing the origins and character of totalitarian ideologies. He refers to this in a humorous story, mentioned in the Autobiographical Reflections, in which he describes his encounter with the Gestapo:

“.... in the general survey of university personnel, a Gestapo officer came to our home and searched around my desk, drawers and bookcases in order to see what I did. [...] First he inspected my desk for incriminating material [...]. I had of course standing on my shelves the principal sources of a political nature: Hitler's Mein Kampf, Kurt von Schuschnigg's book, Dreimal Österreich; Mussolini's Dottrina del Fascismo; and Marx's Communist Manifesto. So he took away Schuschnigg and Marx. I protested that this would give an unfair impression of my political interests, which were strictly impartial and suggested that he take along Hitler's Mein Kampf. But he refused..." (Voegelin, 1996, p. 54).

Of course, joking with the Gestapo could not get a specialist in political thought very far in inter-war Austria. Eventually, Voegelin had to emigrate to the USA. And it was there that he wrote all his major works. The 1958-1969 period which he spent back in Germany, at Munich's Ludwig-Maximilians-Universität, was, according to Voegelin's own account, uneventful and left him embittered about the ethical and intellectual condition of post-war German academia.

Voegelin's early works on religion and politics centered on the totalitarian notions of the society and the state. In the USA, however, he ventured to undertake a more complex criticism of modernity. This approach was visible especially in his famous New Science of Politics (1987), Order and History (2001) and From Enlightenment to Revolution 
(1975). In the above works Voegelin tried to understand both the modern reductionistic thinking about politics and the antimonies of a civilization that so easily shifts from ideological frenzy into consumptionist apathy. Soon, Voegelin reached the conclusion that the essential element which combined all the major politico-philosophical problems of modernity was the attempt to overcome the tension between the immanent reality and what used to be "the Christian eschaton" (Voegelin, 1987, p. 166). This intuition may seem banal, but it is closely connected with Voegelin's original and controversial interpretation of the history of political philosophy and his unique, ahistorical ontology of political phenomena.

As for the description of the subject matter of the history of political philosophy Voegelin, as John H. Hallowell puts it, became convinced "that it was societies and not ideas that were the real entities and that societies expressed themselves in history through a variety of complex symbols" (Hallowell, 1975, p. vi). Words like polis, republic, revolution, progress and so on were, therefore, meant to express some hidden meaning on which the whole of society agreed, even if it differed about the concrete ideas it attached to those symbols. This use of the word "symbol" as opposed to "idea" or "ideology" is clearly visible when Voegelin describes Joseph de Maistre as just another man of the Enlightenment, who believed that will and argument alone can change society. Thus, for all his criticism of the Revolution and progress, de Maistre's vision of politics, remained confined within progressive symbolism. To quote Voegelin:

\begin{abstract}
"If we assume that de Maistre did not consider his work a vain exercise, we must also assume that he seriously believed he could change the course of Western history by a clear analysis of the problem of the crisis and by suggesting the only organizational solution that seemed to make sense. That the critical situation of the whole civilization that has been in the making for centuries cannot be transformed into a harmonious order over night by an act of insight and by an agreement between intelligent people, or that something might be profoundly wrong not only outside Catholicism but within the Church itself, was not sufficiently clear to him, just as it was inconceivable to Comte that he could not restore the order of a civilization by his personal renovation or that anything could be wrong with his religion of humanity. In De Maistre as in Comte we sense the touch of enlightened reason that blinds the working of a spirit" (Voegelin, 1975, p. 184).
\end{abstract}

Symbols, however, by definition, need to refer to something. Hallowell in his description of Voegelinian symbolisms was deliberately coy and avoided going against the distinctively modern sensibilities. According to Voegelin, societies do not simply 'express themselves', they express what they experience as the divine or, as some put it, 'transcendental', order. Moreover, Voegelin does not hesitate to assume that a common ground for all those experiences does indeed exist, and he is not particularly worried that this ground has so far not been reached with the methodological tools developed by the natural sciences. In Anamnesis the thinker notes that "history becomes a structurally intelligible field of reality by virtue of the presence of the ground in which all men participate" (Voegelin, 1978, p. 180). Of course the experiences of the 'ground' are subject to constant differentiation, but at the same time they have no clear vector of development. Political symbolisms simply appear, develop and disappear within the framework of history grounded in divine experience, rather than in the divine experience grounded 
in history as modern historicism, as its Hegelian, Comtian and Marxian versions would have it.

A problem occurs, however, when symbolisms become too stifled by the confines of the doctrine, since the doctrine always points towards the decisionist approach, i.e. some form of control, especially over the humans who express their experience of the transcendental. Of course, every society needs a doctrinal backbone, but at the same time it also needs to be open to new experience. In their extreme forms doctrines can become just a decisionistic cult of those who chose what is acceptable, overlooking the possibility of a common basis of all political symbols. As Voegelin himself observes, the problem of modern civilization is that "the symbols of ideological dogmatism dominating the Western societies... do not attempt to draw men into participation by persuasion, rather they constitute a language of obsession." This, for Voegelin, is a path taken by those who "have closed themselves against the ground" (ibid., p. 187).

In the New Science of Politics Voegelin attempts to backtrace the intellectual genealogy of such men and examine their inspirations. The line of philosophical heritage, according to him, starts with the ancient Gnostic sects, then develops into the millenarianism of Joachim of Fiore and finally finds its ways into modernity. Irrespective of the relevance of those historical musings the very ontology of the political phenomena used by Voegelin makes him a great dissenter as far as his understanding of the science of politics is concerned. He, indeed, becomes what Ellis Sandoz calls the "mystic philosopher" (Sandoz, 2013, pp. 54-57). At the same time Voegelin agrees with the Cambridge School's view that the beliefs which have influenced politics should not be judged against our contemporary standard of scientificity. For him, this, however, does not imply historical relativism. On the contrary, it compels the student of politics to search for a deeper ground that brings all the divergent political concepts together and at the same time is not just a necessary act in the historical unveiling of Hegel's absolute as an "immanentization of the Christian eschaton" (Voegelin, 1987, p. 166).

\section{Strauss's path to the philosopher}

Like Voegelin Strauss was a German émigré who, after fleeing the crumbling Weimar Republic, found a new homeland on the other side of the Atlantic. And like Voegelin, Strauss too was a famous critic of political modernity. This is, however, where the main similarities ended. We are now in the possession of the volume containing the correspondence between the two thinkers (Cooper, Emberley, 1993). The study of those documents clearly confirms that for all their similarities in their search for the non-historicist elements of political philosophy the two thinkers differed sharply.

While Voegelin ultimately turned towards the divine ground of being as the source of political symbols, or purported source of false symbols, Strauss insisted on separating the revelation and the philosophical noêsis. He searched for the ultimate sources of differentiations within political philosophy, especially in the different approaches to the role of the political thinker and political philosophy. Again, just like Voegelin, Strauss separated the political philosophy proper from the instrumental use of political thought. For him, however, the essential discussion of political phenomena revolved around top- 
ics of a perennial, fundamental character, and thus thinking about them represented a value in itself, referring back to political thinking as a unique activity of the Platonic philosopher.

The disagreement between Voegelin and Strauss was especially sharp when it came to the role of revelation in discovering political symbols and their meaning. This is confirmed both in the letters themselves and in the interpretative essay by Voegelin's famous student (Sandoz, 2006). Strauss's firm stance on the separation of revelation and philosophy, and the constant tension between the two is further confirmed in another monographic work devoted to the theologico-political problem in Strauss's philosophy (Meier, 2006). As Heinrich Meier puts it succinctly: "He [Strauss] considers faith insofar as it can be a challenge to the philosophical life" (2006, p. 20). Of course, the resulting dispute can be in some ways inspiring both to faith and philosophy. However, those two modes of thinking will always use different languages that will define their key terms in direct opposition to each other. "Does philosophy not become a special and conscious way of life solely insofar as it must assert itself against an authoritative objection? Does Calvin's or Luther's 'No' to the quid sit deus not draw attention to the central question?" - Meier notes (ibid., p. 28).

That is why Strauss is so suspicious of Voegelin's analysis of the Gnostic origins of modernity. He actually eschews the whole Voegelinian teaching on political symbols as a representation of the human experience of the transcendental ground of being. For Strauss, political philosophy is separate from any imaginings based on revelation, which in Voegelin's vocabulary is tantamount to the experience of "the ground." In a letter to Voegelin, Strauss writes: "I deny that the "historical fact of the beginning of philosophy consists in the attitude of faith of Xenophanes, Heraclitus, and Parmenides, which you [E. Voegelin] assume. Whatever noein might mean, it is certainly not pistis in some sense" (in Emberley, 2004, p. 76). On the same ground Strauss criticizes Voegelin's ideas about the gnostic genealogy of modernity. "Even if the lines from Joachim (de Fiore) to Hegel exist. They would not bring out the turn to the thoroughly 'this-wordly' philosophy, that is from the eternal to a this-wordly process: one has to bring out as well the turn within philosophy" (ibid., p. 75) - Strauss notes.

In other words, if there is something that modernity immanentizes, for Strauss it is surely not the Christian eschaton. In spite of his dislike for the careless Popperian approach to Plato (ibid., pp. 66-69), Strauss is more inclined to think that it is classical philosophy which in some strains of modernity becomes heedlessly superimposed on nature with some very dire political results. Strauss's criticism of this pathology is based on his Socratic zetetic approach to political philosophy. This teaching consists in "a skeptical rebellion against both the traditional authorities and this original, antipolitical critique of those authorities" (Tarcov, Pangle, 1987, p. 922). What Socrates and Strauss turn to is the philosophical speech and liberal education that is "a preparation to philosophy" (Strauss, 1980, p. 13). At the same time such an education is open to the politics that happens among ordinary people, and in spite of being philosophically inspired discourages attempts to forcefully mold the masses into an improved community.

The belief that with the right means all men can be one day turned into civic persons resembling the Aristotelian spoudaios is for Strauss the fundamental flaw of modern political thought, and at the same time a conviction that all distinctively modern think- 
ers have in common. Strauss sees this assumption both in the Marxism of Alexandre Kojève (Strauss, 1991) and in the renaissance philosophy of Machiavelli, whom Strauss describes as the true father of modern political philosophy.

In his renowned work on Machiavelli, Strauss observers that true Machiavellianism does not consist in a simple rejection of idealism. Indeed, what Machiavelli attempts to do is to reach his own vision of the perfect state defined according to a "low but solid standard" (Strauss, 1984, p. 296). In a certain sense, Strauss agrees with Voegelin that the difference in standards (or ideas) is less important than the difference in the fundamental assumptions about history and order. And the fundamental assumption of modern political philosophy is that philosophy can transform the whole society, and not just some of its admirers. All this new, 'low' standard does is enable philosophy to advocate a much broader use of violent, coercive methods in the attempt to bring the vision of a perfect city to life, rather than let it remain only a "city in speech." According to Strauss, what one finds in Machiavelli's books is a "manifestation of the new notion of philosophy which... understands man in the light of sub-human rather the super-human." But, at the same time, Machiavelli changes the understanding of human nature only as the first step in a scheme to improve that nature and justify the means of such an improvement.

Yes, Machiavelli's human is beastly, but at the same time the Platonic "myth of the metals" that describes the limitations to social engineering does not apply. Corrupt humans can be violently molded and perfected by persons of political virtue without any scruples, they are a universally malleable raw material. It is almost as if Machiavelli stepped down from the elevation of idealism to take a long run-up and eventually jump above it. As Strauss writes in the conclusion of his work on Machiavelli's thought:

"...The scheme of a good society it projects is therefore likely to be actualized by men's efforts... The good society in the new sense is possible always and everywhere since men of sufficient brain can transform the most corrupt people, the most corrupt matter, into an incorrupt one by the judicious application of the necessary force" (ibid., p. 297).

Of course, Strauss sees the same political restlessness and the desire to achieve philosophical goals with unphilosophical means in some of the sophists, the adversaries of the classical philosophers. However, only in modernity with Machiavelli does this trend become so prominent that it shapes how whole generations of educated men and women think about politics.

For Strauss, every form of historicism in describing the legacy of political thought goes back to this Machiavellian vision of politics. Similarly, for Voegelin every form of modern historicism goes back to Joachim de Fiore's teleological vision of time. This is because, according to Strauss, historicism both in its Hegelian and contextual guise is evaluating all events from the point of view of present opinions or describing history as a mere game of impersonal forces (the Machiavellian "subhuman"). For Strauss, both approaches downplay the importance of philosophy and the perennial questions it asks. For him, all historicist methods of looking at history of philosophy fall short of searching for the truth as such.

As for the goal of studying political philosophy, it seems that Strauss adheres to the "old fashioned and simple opinion" (ibid., p. 9) according to which the aim of liberal education is to instill republican thinking about politics as a pursuit of the good of the 
whole, in as many people as possible. Nevertheless, realistically one must assume that this idea will never be instilled in everyone. Therefore, the education needs to be limited to the spoudaios or "gentlemen", i.e. those who show a genuine interest in republican politics and shun the materialism of the oligarchic youth.

The spoudaios is, however, still not a philosopher. A philosopher can in part devote himself to the education of gentlemen, but it is not his most important pursuit. As Strauss's students - Tarcov and Pangle put it in somewhat poetic eulogy:

"The only self-sufficient, solid, painless, and consuming or inexhaustible pleasure is the pleasure of thinking and knowing. The best life by nature, as opposed to convention or imagination, is therefore the life of the philosopher, who lives with a few like-minded friends as a more or less harmless parasite on the fringes of the society" (1987, p. 922).

Strauss, himself, remarks more dryly that a philosopher is "concerned with wisdom, for its own sake." And perhaps for that reason "it is a piece of good luck if there is one alive in one's own times" (quoted in ibid., p. 925).

The preoccupation with the unique nature of philosophy as an end in itself led Strauss to wonder whether true philosophers engage in the art of deception and concealing their genuine teaching from fear of persecution by an ignorant society (Strauss, 1980b). Such an explanation would, indeed, seem plausible, as philosophers are very often seen as those who disturb both the traditional prejudices of the society and the secretive machinations of the sophists and the politicians. According to Strauss, even in the modern world, "the allegedly absolute tolerance turns into ferocious hatred of those who have stated most clearly and most forcefully that there are unchangeable standards founded in the nature of man and the nature of things" (Strauss, 1980a, p. 63). This teaching on "persecution and the art of writing" is perhaps the most controversial part of Strauss's thought, and as such it cannot be discussed at length in this essay for brevity's sake. Nevertheless, let us note that in its most radical form the concept has been widely criticized, even by researchers who value other elements of Strauss's thought. ${ }^{4}$

However, even without the "persecution" argument, Strauss's teaching on the history of political philosophy ultimately becomes circular. In his view, a philosopher should not mix philosophical noêsis with political doxa not because s/he needs to preserve the separation between theory and life. The ethical concerns for the welfare of the society are not a viable argument either. The philosopher, according to Strauss, needs to limit his/her own desire to "immanentize" the good city simply in order to defend philosophy from the society, purely for philosophy's sake.

\section{Conclusions}

Both Strauss and Voegelin attack historicism in search of objective truth. They, however, attack it from different angles. Voegelin searches for a metaphysical experience that grounds law and politics in a higher order. Strauss, seeks a pure philosophy that none of its adepts will dare to mix with the political doxa or religion. At the same time this pure

\footnotetext{
${ }^{4}$ For further discussion see (Kuz, 2013).
} 
philosophy of politics would explain all political phenomena to its students, or at least all the Western political phenomena.

Moving in those opposite directions, both thinkers strayed away from the standard self-perception of modern humans. As Allan Bloom puts it in his preface to Kojève's Introduction to the Reading of Hegel, it is one of the most basic features of modern people to think "that thought is relative to time" $(1969$, p. x). Voegelin will thus strike them as a mystic who has no place in academia, and Strauss as a bookish admirer of the ancient Greeks who can only be confined to the lecture hall, and whose works have no significance for real politics.

Nevertheless, the urge to understand the most basic building blocks of political thought, the notions that do not change with time (or change very little) does return, and along with it the old Straussian and Voegelinian arguments. The political philosopher in the postmodern situation can, like Alasdair MacIntyre, defend the small "moral community" (1981, pp. 257-263) of the spoudaioses, or like Agata Bielik-Robson (2008) search for dii absconditi - hidden gods (and demons) in what used to be a neatly organized history of political thought. All such inquiries, however, follow in some way in the footsteps of Strauss and Voegelin.

\section{Bibliography}

Bielik-Robson A. (2008), Na pustyni. Kryptoteologie późnej nowoczesności, Universitas, Kraków.

Bloom A. (1969), Introduction, in: Kojève A., Introduction to the Reading of Hegel. Lectures on the Phenomenology of Spirit, Cornell University Press, Ithaca.

Emberley P., Cooper B. (eds.) (2004), Faith and Philosophy, The Correspondence Between Leo Strauss and Eric Voegelin, University of Missouri Press, Columbia-London.

Gontier Th. (2009), From Political Theology to Political Religions: Eric Voegelin and Carl Schmitt, "Voegelin View", http://voegelinview.com/voegelin-and-carl-schmitt/.

Hallowell J. H. (1975), Editor's Preface, in: Voegelin E., From Enlightenment to Revolution, Duke University Press, Durham.

Kojève A. (1969), Introduction to the Reading of Hegel. Lectures on the Phenomenology of Spirit, Cornell University Press, Ithaca.

Kuź M. (2013), Ahistoricality of the American Mind: On the Origins of the American Left's and Right's Taste for General Ideas and Dislike of History, "Horyzonty Polityki - Horizons of Politics", vol. 4 , no. 9.

MacIntyre A. (1984), After Virtue, University of Notre Dame Press, Notre Dame.

Mansfield Jr. H. C (1975), Strauss's Machiavelli, "Political Theory", vol. 3, no. 4.

Meier H. (2006), Strauss and Theologico-Political Problem, Cambridge University Press, New York.

Pocock J. G. A. (1975), Prophet and Inquisitor: Or, a Church Built upon Bayonets Cannot Stand: A Comment on Mansfield's 'Strauss's Machiavelli', "Political Theory”, vol. 3, no. 4.

Skinner Q. (1969), Meaning and Understanding in the History of Ideas, "History and Theory", vol. 8, no. 1.

Sandoz E. (2013), What is a Mystic Philosopher and Why it Matters: A Note on Voegelin's Political Theory, in: Give Me Liberty, St. Augustine Press, South Bend.

Sandoz E. (2006), Medieval Rationalism or Mystic Philosophy, in: Republicanism, Religion and the Soul of America, University of Missouri Press, Columbia-London.

Strauss L. (1980a), Liberalism Ancient and Modern, Basic Books, New York. 
Strauss L. (1980b), Persecution and the Art of Writing, University of Chicago Press, Chicago-London.

Strauss L. (1984), Thoughts on Machiavelli, University of Chicago Press, Chicago-London.

Strauss L. (1991), On Tyranny Including Strauss-Kojève Correspondence, The Free Press, Torronto.

Tarcov N., Pangle T. L. (1987), Leo Strauss and the History of Political Philosophy, in: History of Political Philosophy, eds. L. Strauss, J. Cropsey, The University of Chicago Press, Chicago.

Voegelin E. (1987), New Science of Politics, Chicago University Press, Chicago.

Voegelin E. (1999a), Authoritarian State, an Essay on the Problem of the Austrian State, ed. G. Weiss, University of Missouri Press, Columbia.

Voegelin E. (1999b), Political Religions, in: Modernity without Restraint, ed. M. Henningsen, University of Missouri Press, Columbia, pp. 19-75.

Voegelin E. (2001), Order and History, ed. E. Sandoz, University of Missouri Press, Columbia.

Voegelin E. (1996), Autobiographical Reflections, ed. E. Sandoz, Louisiana State University Press, Baton Rouge.

Voegelin E. (1978), Anamnesis, trans. by G. Niemeyer, University of Missouri Press, Columbia.

Voegelin E. (1975), From Enlightenment to Revolution, Duke University Press, Durham.

\section{Zdania odrębne w teorii polityki: Voegelina badanie symboli i Straussa poszukiwanie filozofa}

\section{Streszczenie}

Artykuł opisuje metodologiczne podejścia Erica Voegelina oraz Leo Straussa w zakresie studiów nad historią myśli politycznej, zwłaszcza zaś historią zachodniej myśli politycznej. Artykuł stawia tezę, iż obaj myśliciele oddalają się od głównego nurtu metodologicznego, który jest obecnie reprezentowany przede wszystkim przez przedstawicieli kontekstualizmu. W swoich poszukiwaniach obaj podążają jednak zupełnie odmiennymi drogami. Voegelin skupia się na badaniu symboli politycznych i ich zakorzenienia w metafizycznych doświadczeniach ludzi je tworzących. Strauss natomiast bada raczej odwieczne pytania filozofii, stosuje też pojęcie klasycznej dyskursywnej racjonalności jako kryterium oceny odpowiedzi na kluczowe zagadnienia filozoficzne. Obaj myśliciele różnią się też w sposobie postrzegania roli filozofa polityki. Dla Voegelina miałby on/ona konserwować lub współtworzyć swego rodzaju wiary polityczne. Dla Straussa zaś filozof to nauczyciel politycznie rozwiniętej młodzieży, a przede wszystkim obrońca samej filozofii, jako najszlachetniejszej formy działalności umysłowej. W końcowej części artykuł opisuje znaczenie obu autorów dla współczesnej myśli politycznej.

Stowa kluczowe: Voegelin, Strauss, filozofia polityczna, symbole, historia myśli politycznej 
